\title{
Building Bridges: A Conversation between Friends, about Language, Laziness, and Long-distance Running
}

\author{
Matilda Tucker ${ }^{1}$ and Hannah Clarkson ${ }^{2}$ \\ ${ }^{1}$ Independent Researcher, Berlin, Germany \\ E-mail: matildatucker@gmail.com \\ ${ }^{2}$ School of Arts and Humanities, Royal College of Art, London, UK \\ E-mail: hannah.clarkson@network.rca.ac.uk
}

"Marco Polo describes a bridge, stone by stone.

'But which is the stone that supports the bridge?' Kublai Khan asks.

'The bridge is not supported by one stone or another,' Marco answers, 'but by the line of the arch that they form.'

Kublai Khan remains silent, reflecting. Then he adds: 'Why do you speak to me of the stones? It is only the arch that matters to me.'

Polo answers: 'Without stones there is no arch."'

- Italo Calvino, Invisible Cities

This conversation took place in a shared Google Doc over several occasions in April and early May 2021, between friends and colleagues, artists and writers, Hannah Clarkson and Matilda Tucker, in the context of an ongoing experiment in collaborative writing.

In their individual and collective practices, Clarkson and Tucker explore potential embodiments in language(s) of thinking and dwelling in the 'here and elsewhere' of places and spaces they may not physically be in, across cultural, geographical and/or emotional distance. They are interested in how language can be employed as a tool for empathy beyond concrete linguistic understanding; how translation as method opens up to modalities of fictioning and collective storytelling; and writing as an experiment in sharing everyday struggles and building collective narratives of care.

An attempt to bridge gaps between the here and elsewhere of Stockholm, Berlin and all the other places that in this time of pandemic we cannot be, the text below is not a conclusion but a conversation. It is a thinking out loud - or rather, on screen - together, on themes of language and translation; belonging and resisting; work and laziness; former and formless selves. ${ }^{1}$

Keywords: language, politics of home, laziness, translation, care

\footnotetext{
${ }^{1}$ This piece came into being as part of Tucker and Clarkson's development of collective methodologies in the Fiskis Collective. Founded in Stockholm, the collective is comprised of four artists - Clarkson (UK), Tucker (US/Germany), Konstantina Pappa (Greece), and Milagros Bedoya (Peru) - with backgrounds as various as visual arts, writing, and architectural practice, focusing on the potentialities of storytelling for empathy and political agency. Faced with the geographical limitations of the pandemic and the challenge of staying connected when the collective's members are confined to different geographies spanning from Stockholm to Lima, Berlin, Agrinio, and Cambridge, together they ask the question: How to inhabit a place we are not physically in? (https://www.fiskiscollective.com/info)
} 


\section{Мио, мой Мио!}

-Astrid Lindgren

Matilda: I've been interested in the different ways you can open up how to approach a new language. Like your new friend, let's say. If you have many languages at your disposal, how would it change what you're doing if you don't use English, for example, but French to learn Russian? Yesterday I listened to a recording of Astrid Lindgren's Mio my Mio in Hebrew. I only understood about 80 percent, but I imagined all the young Israelis, listening, and imagining what it would be like to be Swedish in the sixties, as the Israeli narrator struggled to pronounce the names Wilhelm, Bosse, and Västerbrogatan.

Hannah: I used to sit on the bus when I first moved to Sweden and repeat all the names of the stops as we passed them. One day, and then every weekday after that, a little girl came and sat next to me on the high up seat at the front of the bus, and asked me my name, where I came from, my age. We had the same conversation each day on our way to our respective schools, and I began to feel at home, at least with those questions and those words. Then I moved to another part of town, and I never saw the little girl again. I guess she is taller now.

Matilda: It's rare that strangers come up to you without prompting in Sweden, in my experience at least. Even rarer that anyone opens up to you.

Hannah: Opening up, what does that really mean when we think about it? Opening one's mouth and chewing on all these new words, trying to spit them out again but they sound strange and unfamiliar. Like the first time you eat an apple pie that was not made by your own grandmother, and realise that not everything is the same, even if there is a certain familiarity there.

Matilda: Someone, a very advanced, autodidact genius-type person, once told me that he retains so much knowledge with such ease because he imagines every new book he reads as a conversation with the author. Before he begins reading, he flips to the author page and studies the photograph, intensely visualizing what that person would be like if they were sitting in front of him in the flesh. That way, every book was an intimate conversation with a new friend. Not sterile information, but heartfelt life advice.

For me, a new language can be a similar friend. Or maybe for now just an acquaintance who you only run into at parties where they've drunk too much (back when we used to have parties, anyways).

Hannah: I feel that way too with authors, and also artists whose work I admire. I wonder what it means to have such a one-sided relationship with someone I have never met, who might even have lived long ago or in a distant context, though I often feel I know them intimately. They live inside my head, and sometimes I even make objects for them - a jacket belonging to an older brother which allowed a young woman access to a male-only art academy; a bowling alley to help a factory owner to realise his sporting dreams perhaps to materialise our relationship in some way, or to give something in return for all the words and thoughts I have borrowed from them. We create our own language in this exchange, and these semi-fictions which emerge are a conversation, though contorted in space and time. Does a conversation only happen between two people in the same time, in speech or writing, or can it exist otherwise?

Matilda: I suppose our inner worlds mirror each other in a whole lot of ways. I think I've mentioned this to you before: what gets me through many a difficult day is the realization that there is a planet - a plane of existence if you will - where all of us people with too many roots and geographical flux and scattered lives, whatever you want to call it, convene together. Because there it makes sense that you'd choose to distribute yourself thusly that you live in country A, you commute for work projects in country B, your family is distributed across countries C.1 and C.2, and your social life is mainly in country $\mathrm{D}$, where you lived last. Possibly you also have a long-distance relationship in another location (not) of your choosing.

Hannah: To live like that is exhausting and exhilarating at the same time.

Matilda: And also a great escape, whatever that means to you.

Hannah: I have realised (perhaps this ought to have been obvious to me before) that I always take myself with me wherever I go, even if that me changes each time my body shifts location.

Side note: I often get a spark of discord when you spell 'realise' with a ' $z$ ', and I wonder what that says about me as a supposedly decolonial thinker towards language. But ultimately it doesn't matter, because when we talk or write together, what happens is so much bigger and more exciting than that ' $s$ ' or ' $z$ ', and it is colo(u)rful whether there is a ' $u$ ' in there or not, because you and I becomes we. 
Matilda: Haha, just seeing you type this right now I'm getting flashes of the corrective impulse I get whenever I see you write "decolonize" without a " $z$ " ...

$* * *$

\section{"Wie gut spricht eigentlich ein*e Muttersprachler*in die eigene Muttersprache? Eher auf dem Niveau von Goethe oder dem von Dieter Bohlen?"12}

-Olga Grjasnowa, Die Macht der Mehrsprachigkeit: Über Herkunft und Vielfalt

Matilda: You know, I had the realization yesterday that you and I were among the three only people in our seminar who speak English as a mother tongue. And what an incomprehensibly great privilege it is! Even though we counted back then and we had something like 18 languages in the room, to which our knowledge contributed in no small way, the unrelenting presence of this "upper hand" seems absurd. Also, what on earth is a "mother tongue?"

Hannah: I wonder whether that is why we are the two who speak the most in seminars... is it to do with language, or just that we always have something to say? I sometimes feel embarrassed that my voice is often one of those most heard, but then I think it's a shame to leave silence after someone has been so generous with their words or thoughts in a presentation or seminar. To respond is a sign of sharing and appreciation, I feel.

Matilda: Or maybe we're just those annoying people who like hearing themselves talk.

Hannah: Also, regarding the 'mother tongue', my mother definitely speaks more than my father does - perhaps that's why I pronounce certain words with a Northern Irish lilt, though that accent has migrated south somewhat since I met L. If we ever have children, I wonder if they will have a 'father tongue' instead, since he talks even more than I do.

Matilda: Wait, I need to think for a second.

Hannah: Take all the time you need.

Hannah: We have a lot of time right now.

\footnotetext{
${ }^{1}$ How well does a German native speaker speak their own mother tongue? More on the level of Goethe or on that of Dieter Bohlen? After all, both are native German speakers.
}

$* * *$

\section{"Ich bin geimpht!"}

-Matilda’s Pap

Hannah: Language is also a time-based medium. It takes time to learn a new language, how to speak or read, and even longer to write it, just as it takes time to get to know a new friend, to truly understand them, their quirks and stammers and what they really mean when they use certain words. To think beyond capitalist understandings of investment, to learn a language is to invest time, to care, to try to empathise with a person or place. Perhaps, as with any investment, we still expect something in return, but that expectation is more a longing to belong, to feel at home, to express oneself in relationship with others.

Matilda: Sorry for my return bar mishaps. I think my problem with the term "mother tongue" is the implication that we need to dig for an "original" language. That the first language you learn to speak should also be the one that you are most comfortable in. That there must be a language in which you understand all the niceties and underhand implications and double meanings and references. That to have a language in your life would mean to know it "to the end." That that is what being at home in a language means. That, for example, a child whose family moves, who has to learn many languages to adapt to new surroundings and maybe struggles with that, forgetting and relearning in turn - and as a result floats between a number of languages, not quite "at ease" in any in specific periods of time until they get used to it-would have something "untrue" or "treacherous" within them. Because there is that strange standard of what it means to "know" a language.

Hannah: It is interesting then, as artists and writers, that we feel the urge to find our own voice, our own language or style, in the way that we write and the things that we make. As though the language(s) we were 'born into' is inadequate to express who we are as individuals. Does this happen to the same extent when we work collectively? I feel like you and I have definitely developed a certain mode of thinking that allows us to communicate and create together as one brain.

Matilda: Definitely. I see this kind of collective writing methodology also tapping into parts of myself which I don't

\footnotetext{
${ }^{2}$ Translations are the authors' own.
} 
have access to otherwise when I'm writing on my own because I see certain things in you that I recognize or bounce off of or, in other cases, that confuse me.

Hannah: Maybe that's also what language is for in its function as communication - in conversation, we find thoughts we didn't have to articulate so perhaps subconsciously didn't bother to fully form. But in sharing, things start to make sense. Or they don't, but become something else, however lucid or confused.

Matilda: And also, as far as how artists and writers relate to the languages they are born into, no one is "interrogating" how good of a "native speaker" the guy down the street is compared to the poet laureate...

Hannah: Hmmm, that's interesting. I was talking to $\mathrm{L}$ about this the other day, in relation to a book written about Germany, in French, by an American author, which won the Prix Goncourt (Les Bienveillantes by Jonathan Littell). Often the books that win that particular prestigious prize are written in 'high' literary French, but in this case there seems to have been an acceptance that as the author is not a native speaker, allowances could be made for occasional clumsy use of language, due to the superb detail of research and storytelling in the novel's contents. Incidentally, the book also won a British annual prize for the worst description of a sex scene, though I'm not sure if that is then down to the author, or the person who made the English translation?

Matilda: That's pretty funny. I will just drop a few breadcrumbs from Olga Grjasnowa's book Die Macht der Mehrsprachigkeit: Über Herkunft und Vielfalt, because I cannot help myself and it's just "drippingly" dense with thoughts about all of this considering what a short read it is. She points out the lengths it takes to be taken seriously as a German speaker, how people are scrutinized for tiny mispronunciations or case mistakes if they apply for university, for instance. Terms like Halbsprachigkeit are used. But when Prince Charles gave a speech in front of the Bundestag, in which he kept switching to English because his German was very rusty, essentially speaking English half the time, the German newspapers still ran a headline that said that Prince Charles had delivered his speech in German.. No mention of Halbsprachigkeit (Grjasnowa 667).

Hannah: I mean, I suppose he did give half a speech in German, or a speech in his version of German. But I see your point about the double standard there. I recently had a conversation about that in relation to University applications here in Sweden too - essentially you can't do a Bachelor's unless you have a piece of paper saying you speak Swedish (same thing in England actually), even if you speak or write well enough to fully engage in the education but never formally studied the language.

Matilda: Grjasnowa lays out these problems in the German context very clearly. It is no innocent accident that "Heimat," the German word for home, is always in the singular. A culture championing monolingualism, after all... It's an expression of ethnic nationalism. She writes,

Der Begriff „Muttersprache”, eines der deutschesten Wörter überhaupt, impliziert hier wieder, dass man nur eine Sprache haben kann, wie man nur eine Mutter hat. Die Muttersprache wird als etwas „Natürliches” hingestellt, die Kultur wiederum als etwas Biologisches und Angeborenes. (49)

Do you need to do a language test for a residency permit or citizenship test in Sweden?

Hannah: I don't think so for residency (at least not as a white European), but perhaps for citizenship you do... and I'm pretty sure it's a requirement if you are not from an EU/EEA country. The citizenship tests in the UK are pretty ridiculous, no person born in Britain would know the answers (and some of the facts are actually even wrong!)

Matilda: Interesting. This reminds me of how different foreigners are put into boxes in Germany -especially in the non-EU visa lines (the short ones are for USA, New Zealand, Australia etc, the long ones are everyone else). And, my own father, a non-German from that short-line group I just mentioned, who has embodied a very conflicted non-Germanness all my life, just now texted me in German:

\section{Ich bin geimpht!}

(I am vaccinated! But he mixed up the " $\mathrm{f}$ " sound, it should be "geimpft.")

Hannah: Does it mean something else with the 'ph'? I like how it becomes like an acid test, literally testing how hot you are at the language.

Matilda: Haha. No, it means nothing else. But it's that weird disconnect, twisted recognition thing again that I can't quite put into words yet. Same as when I saw the Yiddish Corona poster in Stockholm, thought it was Hebrew, only to discover German meaning inside the letters after much puzzling... and then later learning that Yiddish is an official minority language in Sweden.

Matilda: Which leads me back again to seeing a language through the eyes of another language... you've got the rules of reality and gravity and up and down (i.e. spelling, the 
feel of a language) so ingrained that it's hard to do anything but transfer it onto the new language. If you are living a monolingual reality, at least.

Hannah: Haha. I feel the same about Sweden sometimes, the bureaucracy is so boxy that it can't accept that I am both British and Irish (thus European)... I'm like, fine well I was planning to leave soon anyway, so yah boo, shucks to you! (as my sister would put it).

Matilda: Same if German white people study Arabic, it doesn't have to be anywhere near the level that say a Syrian professional's German must be to work as a journalist.

Matilda: Also, Grjasnowa brings up Nabokov's Ada or Ardor: A Family Chronicle, in which he is constantly jumping back and forth between French, Russian and English, which was apparently a nightmare for translators to work on, and only really makes sense completely to people who speak all three languages (I haven't read it).

But I'd like to go into that kind of territory more.

$$
* * *
$$

\section{Rad je bolest (Karl Marx)/ Work is Disease (Karl Marx)}

-Mladen Stilinović

Matilda: Off the bat, I'm pulled back to our conversations about the puritan work ethics of North America and the UK whose yokes we have "suffered" (?) from our whole lives, and which we don't seem to be able to free ourselves from completely... because deep down somewhere, we truly subscribe to them, we buy into them. Perhaps we even get our sense of worth from them.

I also see in this short piece an intriguing intersection of some key components of our individual work in a way that we haven't quite put them into conversation with each other yet: care - the body - the intensity of non-doing, of non-action. I'm curious to hear your thoughts on "work is a disease."

Hannah: If work is a disease, then disease could be defined as anxiety, perhaps. And if anxiety and disease are two sides of the same coin, then that separation between mind and body necessary for capitalism to function at its most profitable - and destructive - is undermined. An awareness of the body and its entanglement with thought and feeling does not come naturally anymore. We are trained to think only of the body when its supposed needs can be satisfied by spending the money we beget by work: a prepackaged sandwich and an overpriced coffee grabbed in a short lunch break from an office desk; a gym membership, sometimes paid for by the boss of said office, in order to keep the body and mind healthy, thus better able to work more; a rented room - shelter - in a faraway part of town, requiring longer working hours to pay for, and an hour and a half on crowded transport to reach.

Matilda: If work is a disease, what could healing look like concretely? If work is a disease, what could preventative care look like?

Hannah: To be over simplistic, Universal Basic Income? Seriously though, I think if we reassess what we think of as work, and value various kinds of labour equally - domestic, artistic, service, or if people still choose it, office work then attitudes around work could begin to be healed. It is perhaps not work itself that is the disease, but the way in which we value or negate it in its various forms. If motherhood, or artistic practice, or other kinds of nurturing, were to be named as the work that they are, care would become more inherent in our understandings of work and the people who enact it.

Matilda: I agree. I think bringing "care" and "work" in direct proximity of one another, as terms, as concepts etc. is more than overdue. Perhaps it would make more sense to start thinking of most types of work as manifestations of care, rather than focusing on presenting and valuing care as a form of work, as I see it being discussed more and more right now. I still think that this is important, but I'd like to go further.

Hannah: I also think it's important to think about who takes on the work of care and in what sense. I was reading Françoise Vergès' Capitalocene, Waste, Race, and Gender recently, in which she points out the invisibility of the (often black and female and in their forties-ish) people who create the conditions for white corporate bodies to take care of themselves very visibly, with their power smoothies and early morning runs, at the same time that those who clean their offices and gyms are taking the bus exhausted home to care for their own children before heading to a rich neighbourhood to look after someone else's. It also made me think about where we sit in that? As non- or low-earners but still engaging in some of those same 'wellness' practices... I guess the difference is that we run to take care of ourselves and lessen the anxieties of being 'out-of-work' or investing so much emotional energy in the work of making art and being in the world in a way that is ethical and politically engaged. 
Matilda: We live in this self-care generation. I think it's really weird that I turned into a young adult who exercises. My teenage self would be really weirded out to see me doing calisthenics and yoga. The sports people were the horrible people in school time. Sports and moving your body was the opposite of me or anything remotely desirable. Flying balls were to be avoided at all costs. And yet here we are, running around, staying fit.

Hannah: Oh me too! I could never have seen myself running, let alone enjoying it! But in some sense I am aware that, given my medical history and the 'wasted time' of being ill in my teens, I am now running away from that body that once (or many times) failed me, and sometimes still does.

Matilda: That makes sense. Also the small detail that it's good for you to take care of your own body, but that overlooks that sports in teenage time (or anytime) $=$ organized fun.

\section{Hannah: And therefore NOT FUN!!!}

Matilda: In the early labor struggles in the United States, the rallying cry called for eight hours for work, eight hours for rest, and eight hours "for what we will" (Weeks 169). I have spent a large portion of this year asking myself what this "for what we will" actually means. It takes surprisingly many different faces once you try to pin it down, and it is an opening to possibilities. Could (preemptive) care in this sense be about un-learning how to do and relearning how to be lazy, so that we can come up with new approaches for what to do with our time?

Put more bluntly, I think this is the first time I see a direct connection between your interest in care and mine in free time and "nothing time"... or rather, the direct implications of care of the latter.

Hannah: Yes, I think that nothing time needs to be cared for, rather than taken care of by filling it with activity in order to assuage the guilt of laziness or nonproductivity. Or the guilt of spending time doing something because it is enjoyable, not because it will earn you money or make you a better person. Like, I should be working right now; or I should cook a healthy meal; or I should exercise; or I should read a book instead of watching TV.

Matilda: Right. Where does all this guilt come from? A vague image of self-flagellating monks playing on some projection screen lodged somewhere in the back of our minds?
A communal pressure to do the right thing... manifest destiny ... grand narratives... societal expectations... this could go on forever.

Hannah: Protestant work ethic, or some kind of puritanism... but what about those who are not religious at all? Perhaps society has just retained all the bad parts of the religions it was built on, and invented 'wellness and spirituality' to replace the good parts it left behind? But how do we define good and bad anyway? Maybe it's to do with running? Going back to running, maybe it is a running towards, rather than a running away as I said before... which in principle sounds positive, but it definitely sets up a dynamic of achievement and failure, a capitalist mindset of working towards a goal...

Matilda: Sometimes, running and writing as "productive" activities become almost the same in my mind - in the sense that both can be about discipline and pushing yourself, striving towards something. But both can also be meditative and goal-less in a meditative, freeing sort of way. For you too?

Hannah: Definitely, the latter is better, but maybe a sweet spot could be somewhere between the two? Maybe this is the fear of laziness talking... but I do think a certain amount of discipline is sometimes required to do something you know will make you feel good.

Matilda: Agreed. And I'd also say that fear plays a very big role in all sorts of ways. Also fear of doing (sometimes). Or fear of not doing.

Hannah: Yes, I think for me I have spent a long time being afraid of resting, for fear if I stop I won't get going again.

Matilda: THIS I relate to so much! Probably why I avoided moving to Berlin for so long, because this whole place is like one big work break.

The opposite of Stockholm, in many, many ways. Zero scramble to survive, very easy life.

Hannah: And why do we find the idea of that so hard to deal with?

Matilda: Because there IS a kernel of truth in the work-hard ideology. Because making things, real things, happen, doesn't happen without a great effort. And honestly the whole thing of people taking a rest and getting too comfortable and just never getting up again is all-too-real. Berlin is full of people who are like "yeah I've been working on this film project for like two years, but you know that's my work style, that kind of project needs time..." I'm so afraid of becoming like that. But I'd also say 
that fear and anxiety are the great engines of human ingenuity. Maybe that's why we've been so interested in knowledges of necessity also?

Hannah: Yes, perhaps... and also discourses and embodiments of care?

Matilda: I think so, yes.

\section{Works Cited}

Calvino, Italo. Invisible Cities. Trans. William Weaver. Mariner Books, 1974.

Grjasnowa, Olga. Die Macht der Mehrsprachigkeit: Über Herkunft und Vielfalt. Duden, 2021.

Lindgren, Astrid. Мио, мой Мио! Trans. Tokmakova Irina Petrovna. Machaon, 2014.

Stilinović, Mladen. Rad Je Bolest (Karl Marx)/ Work Is Disease (Karl Marx). Mladen Stilinović, https://Mladenstilinovic.files.wordpress.com/2013/10/WorkIs-Disease.jpg, 1981.

Vergès, Françoise. "Capitalocene, Waste, Race, and Gender." $e$ Flux, no. 100, May 2019.

Weeks, Kathi. The Problem with Work: Feminism, Marxism, Antiwork Politics, and Postwork Imaginaries. Duke University Press, 2011. 